\title{
Customized Service Evaluation by Preference Clarity and Customer Participation in Korean and Chinese Culture
}

\author{
Jong-Kuk Shin ${ }^{*}$, Min-Sook Park ${ }^{* *}$, Jong-Won, Ock ${ }^{* *}$ \\ Dept. of Business Administration, Pusan National University ${ }^{*}$ \\ Dept. of Distribution Management, Catholic University of Pusan ${ }^{* *}$

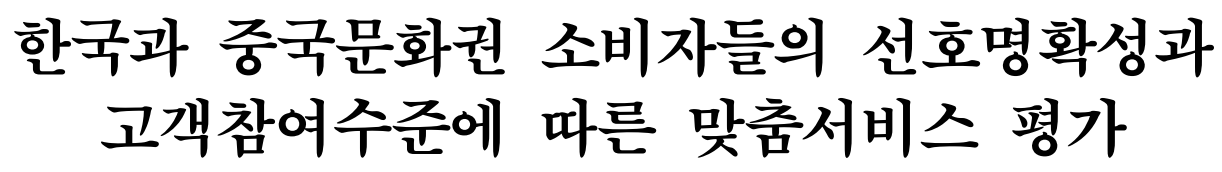 \\ 신종국*, 박민숙**, 옥정원** \\ 부산대학교 경영학과*, 부산가톨릭대학교 유통경영학과**
}

\begin{abstract}
This study examines how preference clarity and customer participation levels affect evaluation of fit toward customized services and also analyzes the effects of cultural difference between Korea and China that may cause variance in the evaluation of fit in the course of interaction with the prior two factors, preference clarity and customer participation level. It conducted a $2 \times 2 \times 2$ between-subjects factorial design adopting preference clarity, customer participation level, and difference of culture. The subjects were composed of 200 Korean and 200 Chinese. According to the analysis results, it is revealed that Korean consumers highly perceived fit toward customized services when their preference is clear and participation level is high, and they evaluate fit more favorably as participation level increased, while Chinese consumers' evaluation for fit deteriorated as participation level increased. The result shows that fit evaluation became more positive through participation when preference clarity is high in Koreans but not in Chinese.
\end{abstract}

Key Words : Customized Services, Preference Clarity, Customer Participation Levels, Cultural Difference between Korea and China

요 약 본 연구는 선호명확성과 고객참여수준이 맞춤서비스의 적합성 평가에 미치는 영향을 살펴보고, 이러한 요인 과 상호작용하여 맞춤서비스 평가에 차이를 보일 수 있는 문화권의 차이로 한국과 중국을 설정하여 $2 \times 2 \times 2$ 집단간 실험설계를 통한 ANCOVA분석을 실시하였다. 한국인과 중국인 각각 200 명을 대상으로 실험을 실시한 결과, 선호가 명확한 경우, 참여수준이 높은 경우, 한국소비자의 경우에 각각 맞춤서비스에 대한 적합성을 높게 지각하는 것으로 나타났다. 그리고 한국소비자들은 참여수준이 높아질수록 적합성이 높다고 평가하지만, 중국소비자들은 참여수준이 높을 때 오히려 적합성 평가가 낮아지고 있었다. 또한 선호명확성이 높은 경우에 참여를 많이 할수록 적합성 평가가 높아지지만, 중국의 경우에는 한국과 달리 참여수준에 따른 적합성 평가 향상이 나타나지 않았다.

주제어 : 맞춤서비스, 선호명확성, 고객참여수준, 한국문화권, 중국문화권

Received 30 December 2013, Revised 5 February 2014

Accepted 20 March 2014

Corresponding Author: Min-Sook Park (Catholic University of Pusan)

Email: mspark@cup.ac.kr

ISSN: $1738-1916$
(C) The Society of Digital Policy \& Management. All rights reserved. This is an open-access article distributed under the terms of the Creative Commons Attribution Non-Commercial License (http://creativecommons.otg/licenses/by-nc/3.0), which permits unrestricted non-commercial use, distribution, and reproduction in any medium, provided the original work is properly cited. 


\section{INTRODUCTION}

Consumer preference does not always appear clearly and preference can be easily changed by surrounding elements which do not seem related to them[1]. According to ELM(Elaboration Likelihood Model), in high involvement situations which customers generally make an important decision, customers evaluate products by depending on essential and central clues through a central route. However, in the case of customized service evaluation, information processing has limits from the start, because evaluation of customized service can be completed when it customized through various service mix rather than circumstance that clear alternative is provided. It is highly possible that nonessential and situational elements through various peripheral routes would be intervened. And in the previous researches on customized service, the importance of a moderating variable has been emphasized[14][16].

Also as seen in the researches of consumer decision making process on consumer preferences, consumers do not evaluate the product after they formed particular preferences, but their preferences are structured at the point of purchase[1]. For the elements which affect the structuring preferences, components of product, characteristics of decision making and situation of selection were presented[11][13]. In particular, Simonson(2005) suggested that preferences on product category is steady[16], but preferences on brand or product in the same category are easily changeable.

If customers participate in the process of customization, criteria of fit evaluation will be strength because customers structured their preferences stronger and it seems that consumers who have low preferences able to evaluate more clear fit evaluation through the process of participation. According to previous researches, in the case of customized service which can not exactly predict the result of service, drawing hypotheses on how customized service satisfies customer preference was limited. Until now, although potential demand on customization is exists continuously, the questions on which degree consumers want for customization, how the level of customization and fit evaluation that required among variety of alternatives are accomplished and what the best method to increase satisfaction of customized service is through interaction with consumers are still remain as a task which should get resolved[7][13]. In this context, in evaluation of customized service, there seem to be effect of clarity of preferences that customers form at purchase process and participation, and the effect of their interaction. In addition, this study covers a subject on cultural difference that can affect purchasing and evaluating customized service based on the study which suggested that the success of marketers who provide suitable customized products for individual preference can be limited by a customer's cultural differences[13].

\section{LITERATURE REVIEW AND HYPOTHESES}

\subsection{Preference Clarity and Customized Service Evaluation}

Customization should make customers express their preferences through communication with individual customer then, develops and offers specific product Firms need effort to find customer preferences clearly and customers need to recognize what services they prefer then express it. If consumers can express their wants clearly that they prefer and if customized service that satisfies these wants clearly can be provided, then, customers will be highly satisfied and obtain good results. However, Kramer(2007) argues that the value of personalization may be limited when customers do not have stable preferences[14].

According to previous researches on consumer preference, there are two reasons on how it is formed. First, consumer preferences are not always clear, and 
well-defined preference insight varies greatly among people[1]. If customers do not have clear preferences, fit evaluation may not be done that their preferences are consistent with customized service that firm provides. Thus, they always should judge that whether customized offer is consistent with their preferences through variety of ways.

The second reason for decreasing value if a consumer's preferences are not well-defined is that preferences can be easily changed to be influenced by many surrounding factors which are irrelevant. Particularly in the case of customized service, a consumer's preferences is not already formed, it is most likely structured during the purchase process [1][16]. If consumers do not know what they really want, they are more inclined to construct preferences based on situational cues when they are asked to specify product requirements. Therefore, the value of customized product may be less important for customers without preferences clarity compared with customer with preferences clarity[14]. The measurement of preferences on customization can be influenced when customers actually have preferences clarity and are sufficiently aware of them[14][16]. Accordingly, in the case when a preference of customized service is well-defined, evaluation of customized service would be accomplished more clearly. Therefore, based on above discussion, the following hypothesis is proposed:

H1. Customers with high preference clarity will evaluate customized service more favorably than those with low preference clarity.

\subsection{Customer Participation Level and Customized Service Evaluation}

According to assertion that a consumer's preferences is newly structured in the process of purchase than being completely formed first and then evaluate the product, it is important to study on moderation variables that influence on this structured process. Therefore, influence such as component of product, characteristics of decision makings, and situation of selection had been examined before[11][15]. In particular, Franke, Keinz and Steger(2009) asserted that convenience of customized service is high when involvement in the product is high[7]. In this context, as participation gets higher, participation will be preferred and participation intention will be greater; thus, favorable evaluation due to participation can be assumed

According to the research of Kramer(2003), the service which produced by consumers who actively participate is likely to perceived as suitable for their preferences[14]. Therefore, if consumers participate in the process of production and communication of customized service, they will perceive this service as more suitable for them and it can be assumed that they probably will evaluate attractiveness higher because they regard customized service which produced by their participation as superior to other alternatives.

H2. Customers with a high participation level will evaluate customized service more favorably than those with a low participation level.

\subsection{Customized Service Evaluation by Cultural Difference}

Historically, Korea and China have formed strong cultural identities, but different cultural values may exist. Particularly in and after the modernization process, each country has had different experiences. In Cheng et al.(1996)'s research, they integrated factors that Chinese place most valuable are harmony, recognition, modernization, saving, and face[2]. Hofsted(1997) classified four cultural value systems that are individualism versus collectivism, uncertainty avoidance, power disparity, and masculism[10]. Korea and China seem to have many things in common in that their power disparity is large and both have a 
collectivism culture. However Korea shows a cultural tendency of feminine and avoiding uncertainty while China has a cultural tendency of masculine uncertainty adoption. In the previous research, it is significant that they examined discriminative result by studying consumer behavior between Korea and China based on culture difference rather than limit Korea and China into a frame which classified as same collectivism culture area.

Kramer et al.(2006)'s research suggested strategies on customized service based on culture difference[13]. He found that consumers who have high interdependence or collective tendency search for products which preferred by customers who are similar with them rather than making a decision based on personal preferences. He also pointed out that customized marketer who simply struggle to success by redesigning the product to fit individual preferences will limit to cultural orientation of customers. Therefore, as of analyzing preferences on customized service based on Hofsted(1997)'s individualismcollectivism cultural tendency, they found that individuals who are independence were more favorable toward customized offer than individuals who are interdependence[10]. These results imply that evaluation of customized service can be different by culture difference.

H3. Perceived preference fit will be altered by cultural difference between Koreans and Chinese.

\subsection{Interaction Among Preference Clarity, Customer Participation, and Cultural Difference}

There are differences between Korea and China. Korea shows cultural tendency that avoided uncertainty, in contrast, China has a culture that adopts uncertainty. These cultural differences are relevant to difference of process in making products to fit customer's preferences while they relieve uncertainty by customer participation. Uncertainty avoidance tendency means the degree that people feel threatened by uncertainty and ambiguity then tries to avoid this circumstance. In cultural areas such as the Unite States, Sweden, Denmark, and China where uncertainty avoidance is low, people are very patient with exceptional cases, because they accept uncertainty which is inherent in daily life, aggressive, and adventurous. Also, they strongly believe that the less stipulated rules are better, and only need to have flexibility. In case of low uncertainty avoidance, it is distinct that people judge by relying on their general knowledge rather than general social norm, have low tension, and believe that they only work hard when they needed it. In contrast, the country where uncertainty avoidance is high, such as Korea, Japan, Germany, and Greece uncertainty is regarded as a constant threat which should be overcome. Therefore, they prefer things are clear and accurate and they try to resist to ambiguous situation. Also, they recognize that they should work hard because they think that they should emotionally busy.

Thus, Koreans who have relatively higher uncertainty avoidance tendency than Chinese are likely to actively take part in participation because they want to avoid the uncertainty of customized service resulting through participation. And this participation will play a positive role in making customized service they wanted. From previous research, the result indicates that China's cultural areas take less cognitive effort than Korea's cultural areas because of social and historical background which have lack prior knowledge and prior information. Furthermore, those causes are the 'Manmandi（慢慢地; slowly, slowly)' tendency of Chinese who are used to the life of co-production and co-distribution. According to this result, Korean consumers prefer to more actively use cognitive effort, they are likely to conduct such customized service evaluation, and the Manmandi tendency means possibility of evaluating customized service based on 
trust rather than an active participation. We can assume that Korea, in contrast, will prefer participation for avoiding uncertainty on time spent in offering customized service because it is represented as a 'Balliballi (quickly, quickly)' culture. Based on these contents, customized service evaluation will be high due to Korean consumers' participation compared to China where uncertainty avoidance is low and take less cognitive effort.

H4. Korean customers with a high level of participation will evaluate customized service more favorably than Chinese customers.

For customers who have unclear preferences, it will be limit to form a favorable attitude on the result even if they participated with low level of expectation on the result of customized service because customized product which provided to customers who have unclear preferences beside customers who have clear preferences can decrease its value[14]. So, it is likely the same as the assimilation effect in the social judgment theory. If preferences are well-defined and participation is a high, positive evaluation will be conducted on customized service through the assimilation effect. It can be said that self-serving effect which consumers believe that they contributed to this result by participation works together.

Therefore, when preferences clarity is high, preferences become clearer by customer participation and there is more favorable evaluation on the result of customized service. However, when customers who have low preferences clarity participate in the service, it may result to positive effect by participation than preferences clarity is high. Because customized service only completed by participation, merits can be fall[6], consumers prefer finished products produced by provider because they bother to participate in, and they may not aware of many benefits provided by customization[9].

Hence, if customers participate in situation where the preferences is clear, evaluation on customized service can be positive by the assimilation effect, but if customers participate in situation where the preferences is low, the contrast effect can be increased by vitalizing pressure on the participation and negative awareness. Thus, improvement in customized service evaluation through participation will be greater when preferences are well-defined. Cultural difference in this interaction should be considered. If preferences clarity is low, then uncertainty perception increases. Therefore Korean consumers try to remove uncertainty through participation and increase fit, but even if Chinese consumer's uncertainty perception does not greatly increase or if they perceived it as high, their tendency which they try to avoid it does not increase, then the contrast effect will be greater. In comparison, Korean consumers will judge that effort to remove uncertainty through participation and consumers who have low clarity are likely to think they had more definite experience through participation.

H5. Korean customers with high preference clarity and a high level of participation will evaluate customized service more favorably than Chinese customers

\section{METHODS}

We used scenario-based experiments to test the proposed hypotheses. It conducted a $2 \times 2 \times 2$ between-subjects factorial design adopting preference clarity (high/low) $\times$ customer participation level (high/low) $\times$ difference of culture (Korea/China). Total 400 subjects were randomly assigned to read one of the eight experimental conditions and then answer questions from a structured instrument (200 Korean and 200 Chinese, 55\% of respondents are female).

On this basis, we first conducted a pilot test to measure involvement level, usage experience, intensity of needs, and attitudes toward customized services on 
20 Korean and 20 Chinese university students. Through this pilot study, the travel agency and fitness service were chosen for the customized services which would be used in our scenario and the beauty parlor service and restaurant service were excluded because there was limitation in those kinds of service situations due to differences in involvement level and usage experience between Korean and Chinese customers. There was no significant difference of involvement level between Koreans and Chinese toward the travel agency and fitness service (travel agency service: Korean (3.64), Chinese (3.79), $t=-1.440, p=.151$; fitness service: Korean (3.97), Chinese (3.82), $\mathrm{t}=-1.653, \mathrm{p}=.099$ ) and both customers' usage experience showed similarity. Also, no statistical difference was not found in the level of needs toward the customized services (travel agency service: Korean (4.40), Chinese (4.24), $\mathrm{t}=1.761, \mathrm{p}=.079$; fitness service: Korean (3.86), Chinese (3.75), $\mathrm{t}=1.312, \mathrm{p}=.190$ ).

Preference clarity for customized services and fit of the services were evaluated in the process of experiment. For manipulation check on cultural difference, the level of uncertainty avoidance was measured. Prior to this step, subjects were required to answer questions for their perceived participation level to verify the manipulation of participation level adopted in the scenario. The degree of time and information input was used for checking participation level in the inquiries[3].

To measure preference clarity toward customized services, subjects were required to describe what they wanted when using the customized service in the scenario. Preference clarity is defined as the extent to which customers know about what they prefer clearly and have the ability to express their preference to service providers[16]. Therefore, we made subjects directly describe what they wanted in the given service situation in order to measure more strictly their ability to express clear preference. Subjects were guided to enumerate various concrete requirements in the given service situation. We divided subjects into two groups, a group with a clear preference and that with a less clear preference by a median value in the numbers of subjects' requirements about the given customized service(median split).

Perceived fit has been identified as a significant factor in brand evaluation. Coulter and Coulter(2002) referred it as the degree to which customers perceived the services offered similar to their own lifestyles, preferences, and tastes[4]. So we presented the outcome of a given customized service to a subject in each scenario and requested the subject evaluate the extent to which the outcome was similar to his/her prior requirements about the given customized service.

The scales of uncertainty avoidance were accordingly adapted from previous researches [5][10] and modified to suit this research. According to existing researches, customers' involvement with products becomes high when they consume them frequently. And their evaluation about the products and future usage intention can be changed by their involvement level[12]. Gordon, McKeage, and Fox (1998) demonstrated that relative effects of customization have positive relationship with involvement level[8]. Therefore, we measured involvement level and prior experience and used them as covariates in the analysis process. All constructs were measured by a 5-point Likert type scale.

\section{RESULTS}

We performed a manipulation check for 'difference of participation level' and 'uncertainty avoidance' through a t-test $\quad\left(\mathrm{M}_{\text {high }}\right.$ participation $=4.02, \quad \mathrm{M}_{\text {low }}$ participation $=3.75$, $\mathrm{t}=-2.569, \mathrm{p}<.000, \mathrm{M}_{\text {high uncertainty avoidance/Korean }}=4.23, \mathrm{M}_{\text {low }}$ uncertainty avoidance/Chinese $=3.02, \mathrm{t}=-12.710, \mathrm{p}<.000)$. To test the hypotheses, we conducted $2 \times 2 \times 2$ ANCOVA taking preference clarity, customer participation level, and cultural difference as independent variables; perceived 
preference fit as a dependent variable; and involvement level and prior experience as covariates.

<Table 1> ANCOVA Analysis
\begin{tabular}{|lcccc|}
\hline \multicolumn{1}{|c}{ Source } & D.F & M.S. & F-value \\
\hline A. Preference clarity (H1) & 1 & 13.096 & 37.616 & ${ }^{* * *}$ \\
B. Customer participation (H2) & 1 & 5.048 & 14.499 & ${ }^{* * *}$ \\
C. Cultural differences (H3) & 1 & 16.304 & 46.832 & ${ }^{* * *}$ \\
$\mathrm{~A} \times \mathrm{B}$ & 1 & 4.409 & 12.663 & ${ }^{* * *}$ \\
$\mathrm{~A} \times \mathrm{C}$ & 1 & .727 & 2.088 & \\
$\mathrm{~B} \times \mathrm{C}(\mathrm{H} 4)$ & 1 & 4.362 & 12.529 & ${ }^{* * *}$ \\
$\mathrm{~A} \times \mathrm{B} \times \mathrm{C}(\mathrm{H} 5)$ & 1 & 2.030 & 5.832 & ${ }^{* *}$ \\
$($ Covariate) Involvement & 1 & 2.413 & 6.931 & ${ }^{* * *}$ \\
(Covariate) Prior experience & 1 & 1.160 & 3.331 & ${ }^{*}$ \\
Error & 379 & & & \\
\hline
\end{tabular}

$* \mathrm{p}<0.1, * * \mathrm{p}<0.05, * * * \mathrm{p}<0.01$

$<$ Table 2> Mean and Standard Deviation

\begin{tabular}{|c|c|c|c|c|c|}
\cline { 2 - 5 } \multicolumn{1}{c|}{} & \multicolumn{3}{c|}{ Customer participation } & \multicolumn{1}{c|}{} \\
\cline { 2 - 5 } \multicolumn{1}{c|}{} & \multicolumn{2}{c|}{ Korean } & \multicolumn{2}{c|}{ Chinese } & \multicolumn{1}{c}{} \\
\cline { 2 - 5 } & Low & High & Low & High & \\
\hline Low preference & 4.02 & 4.23 & 3.24 & 3.14 & 3.52 \\
clarity & $(.58)$ & $(.47)$ & $(1.04)$ & $(1.08)$ & $(1.00)$ \\
\hline High preference & 4.32 & 4.56 & 4.17 & 4.30 & 4.32 \\
clarity & $(.49)$ & $(.45)$ & $(.56)$ & $(.41)$ & $(.48)$ \\
\hline \multirow{5}{*}{} & 4.26 & 4.44 & 3.85 & 3.77 & \\
\cline { 2 - 5 } & $(.52)$ & $(.48)$ & $(.87)$ & $(.98)$ & \multicolumn{2}{c}{} \\
\cline { 2 - 5 } & & & &
\end{tabular}

(Note) The standard deviations are in parentheses.

Hypothesis 1 stated that evaluation of customized services will be favorable when customers' preference toward the services is clear was proposed to examine how preference clarity affects evaluation of fit toward customized services. The result demonstrated that there was a significant relationship between preference clarity and perceived fit toward customized services $(\mathrm{F}=37.616, \quad \mathrm{p}<0.01)$ and fit evaluation was more favorable when preference clarity was high $\left(\mathrm{M}_{\text {high }}\right.$ preference clarity $=4.31, \quad \mathrm{M}_{\text {low }}$ preference clanty $=3.61, \quad \mathrm{t}=105.164$, $\mathrm{p}<.000)$

Judging from the test of hypothesis 2, the main effect of the participation level on evaluation of fit toward customized services was significant ( $\mathrm{F}=14.499$, $\mathrm{p}<0.01$ ). And the result showed that fit evaluation was more favorable when the participation level was high $\left(\mathrm{M}_{\text {high }}\right.$ participation level $=4.18, \quad \mathrm{M}_{\mathrm{low}}$ participation level $=3.93$, $\mathrm{t}=-3.238, \mathrm{p}<.000)$

Next, we examined hypothesis 3 , the main effect of cultural difference between Koreans and Chinese on evaluation of fit toward customized services was significant $(\mathrm{F}=46.832, \mathrm{p}<0.01)$, so hypothesis 3 was supported, too. Comparing average of fit evaluation between Korea and China, we can see Koreans evaluated fit of customized services more favorably $\left(\mathrm{M}_{\text {Korea }}=4.28, \mathrm{M}_{\text {China }}=3.79, \mathrm{t}=-6.471, \mathrm{p}<.000\right)$.

In hypothesis 4 , the interaction effects of participation level and cultural difference on evaluation of fit toward customized services was significant $(\mathrm{F}=12.529, \mathrm{p}<0.01)$. Korean evaluated more favorably since their participation level was high $\left(\mathrm{M}_{\text {high participation }}\right.$ level $=4.44, \mathrm{M}_{\text {low participation level }}=4.26, \mathrm{t}=2.469, \mathrm{p}<.05$ ) while Chinese consumers' evaluation of fit was more positive when their participation level was low ( $\mathrm{M}_{\text {high participation }}$ level $=3.77, \mathrm{M}_{\text {low participation level }}=3.85, \mathrm{t}=-.440, \mathrm{p}<.662$ ). But there was no statistical difference in the evaluation of Chinese. These results mean that Korean consumers perceived customized services more suitable by participating in the service production process.

In hypothesis 5, we assumed that fit evaluation would be more positive through participation when preference clarity was high while fit evaluation would be more negative by participating in the service production process when preference clarity was low. We also suggested that this tendency appeared more stronger in China. The result of testing two-way interaction effects was significant $(\mathrm{F}=12.668, \mathrm{p}<0.01)$ and showed that fit evaluation could be more negative by participation when preference was unclear $\left(\mathrm{M}_{\text {high }}\right.$ participation level $=3.85, \quad \mathrm{M}_{\text {low }}$ participation level $=3.47, \mathrm{t}=-2.206$, $\mathrm{p}<0.05)$ than when preference was clear $\left(\mathrm{M}_{\text {high participation }}\right.$ level $=4.35, \mathrm{M}_{\text {low participation level }}=4.28, \mathrm{t}=1.028, \mathrm{p}=.305$ ). This implies that marketers should raise the participation level for Korean consumers regardless of their preference clarity because through participation their evaluation for fit toward customized services will be more favorable even though their preference is not 
clear; on the other hand, it is desirable not to increase the participation level for Chinese consumers when their preference clarity is low.

As shown in figure 1 (3-way interaction effects), it can be said that when consumers' preference clarity is high, fit evaluation of both cultural areas becomes favorable as participation level increases, however, when consumers' preference is not clear, Korean consumers' fit evaluation still becomes positive while Chinese evaluation becomes negative as participation level increases. According to the test result of two-way interaction effects, there were significant differences in all the cases of Koreans but significant difference did not exist in Chinese. Judging from the results, it is desirable to raise the participation level for Korean consumers in order to uplift preference clarity toward customized services, but not for Chinese consumers. Therefore, hypothesis 5 was supported, and all the hypotheses proposed in this study were supported.

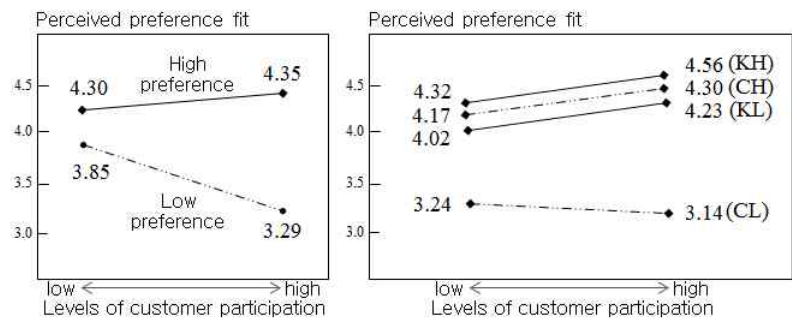

(Note) $\mathrm{KH}$ : Korea, High preference clarity, $\mathrm{t}=2.228, \mathrm{p}=.037$

$\mathrm{KL}$ : Korea, Low preference clarity, $\mathrm{t}=2.811, \mathrm{p}=.007$

$\mathrm{CH}$ : China, High preference clarity, $\mathrm{t}=.995, \mathrm{p}=.329$

CL : China, Low preference clarity, $\mathrm{t}=-.283, \mathrm{p}=.781$

[Fig. 1] The Results of Interaction Effects

\section{DISCUSSION}

According to the analysis results, it was revealed that Korean consumers highly perceived fit toward customized services when their preference was clear and participation level was high, and they evaluated fit more favorably as participation level increased, while
Chinese consumers' evaluation for fit deteriorated as participation level increased. Because there was no significant difference, it could be interpreted that fit evaluation in Chinese is not improved through participation. This also means that Korean consumers' perceived fit toward customized services as enhanced through participation. We analyzed whether this difference would vary by preference clarity. The result indicated that fit evaluation became more positive through participation when preference clarity was high in Koreans but not in Chinese. This result also implied that marketers would be able to make Korean consumers' evaluation more positive by increasing participation levels regardless of consumers' preference clarity, but they would not need to increase participation levels for Chinese consumers to render their fit evaluation more favorable.

The theoretical implications of this study are as follows. First, we verified the effects of preference clarity which was assumed to be an important factor in evaluation for customized services. If researches of customized services are conducted on the premise that consumers form their preferences beforehand or they can articulate them when using customized services, then it is not possible to identify evaluation difference generated by preference clarity. This study examined the difference in evaluation toward customized services by the degree of consumers' preference clarity, and the results showed that fit evaluation toward customized services was favorable when consumers perceived their preference clearly.

Second, this study tested the main effects and interaction effects of essential moderating variables which were changeable by the situations in which customized services were offered and also analyzed the effects by applying theories to concrete conditions. Here we applied the Elaboration Likelihood Model to analyze the process of customized services usage and evaluation. It was based on the assumption that there was limitation in information processing due to 
characteristics of customized services which were produced through collaboration between consumers and service providers, so intervention of nonessential and situational elements through various peripheral routes would play an important role. We also adopted the social judgment theory to explain the effect of participation by comparing consumers with clear preference to those with obscure preference. It was based on the assimilation effect that there were difficulties in forming a favorable attitude toward the outcome of customized services because the level of expectation for it was low when consumers had vague preferences.

However, it is necessary to define the primary cause of why this cultural difference appeared in Koreans and Chinese through more concrete empirical tests. Undoubtedly, we here proposed uncertainty avoidance tendency as a possible cause based on the research results of Hofsted (1997), but if we analyze and present the cause more specifically and deeply in future research, we can contribute to the extension and utilization of researches on consumer behavior.

Moreover, Korean consumers' fit evaluation toward customized services was improved through participation even when their preference is unclear, but the effect of participation was not present in Chinese (there was no significant difference but Chinese consumers' evaluation for fit was deteriorated as participation level increased). We found the interaction effects among preference clarity, participation level, and cultural difference, but there was limitation in identifying the psychological mechanism of these interaction effects. We can only suggest that self-serving bias may be a variable of cultural difference. According to self-serving bias, consumers attribute the successful outcomes produced by their own participation to themselves. It is highly possible that self-serving bias is augmented in Korean consumers by attributing the outcomes of participation to their own responsibility and regarding the outcomes as what they have expected. Future researches should be conducted to thoroughly analyze diverse variables which can occur due to cultural differences between Korea and China and to identify the cause of the results presented in this study.

\section{REFERENCES}

[1] Bettman, J. R., M. F. Luce, and J. W. Payne, Constructive Consumer Choice Processes. Journal of Consumer Research, Vol. 25, No. 3, pp. 187-217, 1998.

[2] Cheng, H., and J. C. Schweitzer, Cultural Value Reflected in Chinese and U.S. Television Commercials. Journal of Advertising Research, Vol. 36, No. 3. pp. 27-45, 1996.

[3] Cindy, C., C. Cynthia, W. Lawrence, The Customer as a Productive Resource: A Pilot Study and Strategic Implications. Journal of Business Strategies, Vol. 18, No. 1, pp. 47-69, 2001

[4] Coulter, K. S., and R. A. Coulter, Determinants of Trust in a Service Provider: the Moderating Role of Length of Relationship. Journal of Services Marketing, Vol. 16, No. 1, pp. 35-50, 2002.

[5] Deleersnyder, B., M. G. Dekimpe, Jan Benedict E. M. Steenkamp, and P. S. H. Leeflang, The Role of National Culture in Advertising's Sensitivity to Business Cycles: An Investigation Across Continents. Journal of Marketing Research, Vol. 46, No. 5, pp. 623-636, 2009.

[6] Fang, E., Customer Participation and the Trade-Off Between New Product Innovativeness and Speed to Market. Journal of Marketing, Vol. 72(July), pp. 90-104, 2008.

[7] Franke, N., P. Keinz and C. J. Steger, Testing the Value of Customization: When Do Customers Really Prefer Products Tailored to Their Preferences?. Journal of Marketing, Vol. 73, No. 5, pp. 103-121, 2009.

[8] Gordon, M. E., K. McKeage, and M. A. Fox, 
Relationship Marketing Effectiveness: The Role of Involvement. Psychology and Marketing, Vol. 15, No. 5, pp. 443-459, 1998.

[9] Hill, K, Customers Love/Hate Customization. CRM-Daily.com, (April 10), 2003.

[10] Hofsted, G., Cultures and Organization: Software of the Mind. McGraw-Hill, 1997.

[11] Huber, J., J. W. Payne, and C. Puto, Adding Asymmetrically Dominated Alternatives: Violations of Regularity and the Similarity Hypothesis. Journal of Consumer Research, Vol. 9, No. 1, pp. 90-98, 1982.

[12] Kaplan, A. M., D. Schoder, and M. Haenlein, Factors Influencing the Adoption of Mass Customization: The Impact of Base Category Consumption Frequency and Need Satisfaction. Journal of Product Innovation Management, Vol. 24(March), pp. 101 - 116, 2007.

[13] Kramer, T. Thomas, S. Spolter-Weisfeld, and M. Thakkar, Individual Preferences Versus Group Preferences: The Effect of Cultural Orientation on Consumer Receptivity to Customized Offers. Advances in Consumer Research, Vol. 33, No. 1, pp. 462-463, 2006.

[14] Kramer, T., The Effect of Measurement Task Transparency on Preference Construction and Evaluations of Personalized Recommendations. Journal of Marketing Research, Vol. 44, No. 2, 22-33, 2007.

[15] Levin, I. P., and G. J. Gaeth, How Consumers Are Affected by the Framing of Attribute Information Before and After Consuming the Product. Journal of Consumer Research, Vol. 15, No. 3, pp. 374-378, 1998.

[16] Simonson, I., Determinants of Customers' Responses to Customized Offers: Conceptual Framework and Research Propositions. Journal of Marketing, Vol. 69, No. 1. pp. 32-45. 2005.
신 종 국(Shin, Jong-Kuk)

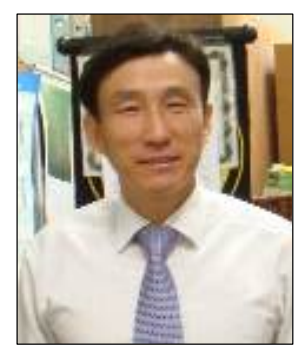

-1985년 2월 : 부산대학교 경영학과 (경영학사)

· 1987년 2월 : 한양대학교 경영학과 (경영학석사)

- 1994년 8월 : 한양대학교 경영학과 (경영학박사)

- 1995년 3월 현재 : 부산대학교 경영학과 교수

- 관심분야 : 마케팅, 유통관리, 광고관리

·E-Mail : shinjk@pusan.ac.kr

박 민 숙(Park, Min-Sook)

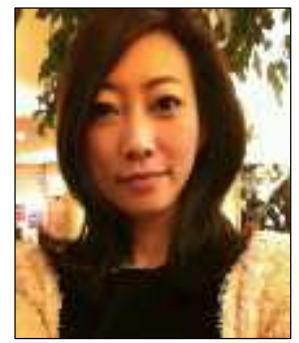

- 2004년 2월 : 부산대학교 경영학(경 영학석사)

- 2008년 2월 : 부산대학교 경영학과 (경영학박사)

- 2012년 3월 현재 : 부산가톨릭대 학교 유통경영학과 교수

- 관심분야 : 유통관리, 소매관리

·E-Mail : mspark@cup.ac.kr

옥 정 원(Ock, Jung-Won)

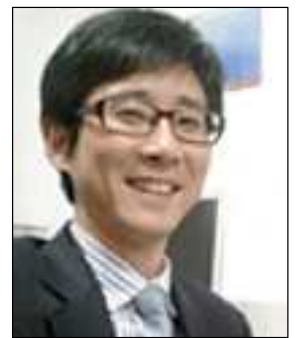

- 2003년 2월 : 부산대학교 경영학(경 영학석사)

·2008년 8월 : 부산대학교 경영학과 (경영학박사)

- 2008년 3월 현재 : 부산가톨릭대 학교 유통경영학과 교수 · 관심분야 : 스포츠마케팅, CSR

·E-Mail : jwock@cup.ac.kr 